\title{
Integrity in Albanian Public Procurement. Principles and the Fight Against Corruption
}

\author{
Ms. Ejona Bardhi (PhD in Process)
}

Professor Faculty of Law, University of Tirana, Department of Public Law

\section{Doi:10.5901/ajis.2014.v3n4p185}

\section{Abstract}

Public procurement is the process of acquisition of goods, works and services financed with public funds or donations. Wayne and Wittig have defined it as "a business process within the political system. This field of public service has been and remains one of the areas most critical, given that even the fact that with time there is a widespread perception of corruption huge presence in this direction. Member countries of the Organisation for Economic Cooperation and Development see public procurement in a broader aspect, including acquisitions, Rental, licensing, exclusive of works, services and supplies of goods that are financed from the state budget or international organizations. The potential for corruption in publik procurement exists in all economies and no sector is free from risks of corruption. However, some sectors were recognised as being particularly exposed to corruption in public procurement, due to the complex nature of the works and the vast amounts of the contracts that are involved (e.g., construction of major bridges, dams or tunnels). International public procurement, that often involves large contracts, can be especially lucrative target for would-be wrongdoers. Many opportunities for corruption were also identified in the delivery of development assistance and corruption was considered by many to be the most important challenge to aidfunded public procurement. The public procurement process can be abused through collusion and corruption for the purposes of political party financing, as well.

Keywords: public procurement,corruption,principles, fight

\section{What is Public Procurement}

In Albania's public procurement procedures are regulated by law. No. 9643, dated 20.11.2006 "On Public Procurement".This law regulates the selection of winners of public contracts in accordance with the following general principles: ${ }^{1}$

a) non-discrimination and equal treatment of tenderers or candidates

b) transparency in procurement procedures

c) demands equality of treatment and of the obligations imposed on the bidders or candidates

All rules that apply to procurement of goods, works and services by contracting authorities defined in the law "On Public Procurement". The purpose of this law is: ${ }^{2}$

a) increase efficiency and effectiveness in public procurement procedures, carried out by the contracting authorities

b) to ensure a better use of public funds and reduce procedural costs

c) encourage the participation of economic operators in public procurement procedures

d) promote competition between economic operators

e) ensure an equitable and non-discriminatory treatment for all operators, participating in public procurement procedures

f) ensure integrity, public trust and transparency in public procurement procedures

For the implementation of this law is in charge of the Public Procurement Agency. It has the duty to submit to the Council of Ministers proposals for procurement rules, to develop standard bidding documents, issued Public Notice Bulletin of the possibility of contracting, to provide advice and technical assistance to public contracting authorities, to present annual report Council of Ministers for the overall functioning of the public procurement system, ${ }^{3}$ to verify the

\footnotetext{
${ }^{1}$ LAW 9643, dated 20.11.2006 as amended by Law no 9800 dated 10.09.2007 PUBLIC PROCUREMENT, article 2

${ }^{2}$ LAW 9643, dated 20.11.2006 as amended by Law no 9800 dated 10.09.2007 PUBLIC PROCUREMENT, article 1

${ }^{3}$ DECISION No. 1, on 10.01.2007 FOR Approval of the Public Procurement Rules
} 
implementation of public procurement procedures and contract enforcement, as well as monitor the progress of the public procurement system through information obtained by contracting autoritetve periodic reports. Public Procurement Agency may exclude an economic operator from participation in procurement procedures, for a period of 1 to 3 years, for the cases established by law.

Procurement Committee is the highest body in the area of procurement, which investigates complaints about procurement procedures, in accordance with the requirements laid down in applicable law. Public Procurement Commission is a public legal entity, under the Council of Ministers. On completion of the review of the appeal, he makes the decisions, which are administratively final.

Public contracts concluded between the contracting authority and the contractor.

"Contracting Authority" is any institution or entity (constitutional institutions, other central institutions, independent central institutions and local government units), subject to the application of the law "On Public Procurement".

"Contractor", "Supplier" and "Service" is any natural person, legal person or public entity or group of persons and I or bodies which offers on the market, one or more jobs, supply goods or services.

Types of public procurement procedures are:
a) open procedure
b) restricted procedure
c) negotiated procedure, with or without prior publication of a contract notice
d) request for proposals
e) design contest
f) procedure "consultancy services"

\section{Public Procurement, A Major Potential for Corruption}

The potential for corruption in publik procurement exists in all economies and no sector is free from risks of corruption. However, some sectors were recognised as being particularly exposed to corruption in public procurement, due to the complex nature of the works and the vast amounts of the contracts that are involved (e.g., construction of major bridges, dams or tunnels). International public procurement, that often involves large contracts, can be especially lucrative target for would-be wrongdoers. Many opportunities for corruption were also identified in the delivery of development assistance and corruption was considered by many to be the most important challenge to aid-funded public procurement. The public procurement process can be abused through collusion and corruption for the purposes of political party financing, as well.

What are the difficulties encountered in the fight against bribery and corruption in public procurement? 4

One of the fundamental obstacles in combating fraud and corruption in public procurement is the sheer difficulty in detecting wrongdoings. The difficulty stems from the fact that there is often clear perpetrator nor victim, rather a group of individuals in collusion, with common interests in maintaining secrecy around their corrupt acts. Corruption in the procuremnt process is hardly limited to straightforward bribery; many sophisticated means of diverting funds and concealing these diversions exist.

A salient point is the very nature of estalished procurement procedures and rules. Indeed, public procurement regulations are designed first and foremost to increase competition, to obtain the best price, and to ensure the quality and timely delivery of products and services supplied to public organisations. Prevention and detection of corruption are not primary objectives of public procurement regulations.In addition, the traditional supervisory and oversight systems implemented by governments, multilateral development banks and other agencies as part of the procerement process are not necessarily adequate to detect hidden and often complex methods of corruption. 


\section{Principles for Enhancing Integrity in Public Procurement}

3.1 Provide an adequate degree of transparency in the entire procurement cycle in order to promote fair and equitable treatment for potential suppliers ${ }^{5}$

Governments should provide potential suppliers and contractors with clear and consistent information so that the public procurement process is well understood and applied as equitably as possible. Governments should promote transparency for potential suppliers and other relevant stakeholders, such as oversight institutions, not only regarding the formation of contracts but in the entire public procurement cycle. Governments should adapt the degree of transparency according to the recipient of information and the stage of the cycle. In particular, governments should protect confidential information to ansure a level playing field for potential suppliers and avoid collusion. They should also ensure that public procurement rules require a degree of transparency that enhances corruption control while not creating red tape to ensure the effectiveness of the system.

3.2 Maximize transparency in competitive tendering and take precautionary measures to enhance integrity, in particular for exceptions to competitive tendering ${ }^{6}$

To ensure sound competitive processes, governments should provide clear rules, and possibly guidance, on the choice of the procurement method and on exceptions to competitive tendering. Although the procurement method could be adapted to the type of procurement concerned, governments should, in all cases, maximize transparency in competitive tendering. Governments should consider setting up procedures to mitigate possible risks to integrity through enhamced transparency, guidance and control, in particular for exceptions to competitive tendering such as extreme urgency or national security.

\section{Conclusions}

Given the fact that public procurements are another area that attracts the attention of the public and not only, for the reason that a large portion of public funds or donations go to the process of acquisition of goods, works and services, recognition of the organization and functioning of represents their fundamental importance.

Based on everything to address the above, we can say that:

First, a need that the administrative process of procurement to be quicker and less bureaucratic.

Secondly, it is necessary that the principle of transparency and equal treatment to be essential and non-negotiable at all associated with public procurement procedures, thus avoiding the corruption of the authorities responsible.

Finally, given that this sector is highly affected by political changes, it is necessary to create sustainable professionals or employees who have knowledge in this field, and their continuous training, in order to increase public confidence in national and international Laws and realized how much better the rights of the parties in the process.

\section{References}

Decision No. 1, on 10.01.2007 FOR Approval of the Public Procurement Rules

Fighting corruption and promoting integrity in public procurement-OECD publishing, ISBN: 92-64-01399-7 $282005081 \mathrm{P}$

Law 9643, dated 20.11.2006 as amended by Law no 9800 dated 10.09.2007 "Public Procurement"

OECD Principles for integrity in public procurement - OECD publishing, ISBN: 92-64-01399-7 $282005081 \mathrm{P}$ 
